\title{
ENVIRONMENTALLY DISRUPTIVE ROAD CONSTRUCTION IN THE QU'APPELLE VALLEY
}

\section{JIM HINES, 3916 Castle Road, Regina, Saskatchewan S4S 6A4}

In southern Saskatchewan, the Qu'Appelle Valley is one of the few tracts of land of which a significant portion remains in a natural condition. Despite the breaking of the rich flood plains, pollution of the water, overgrazing by livestock, the scarring of the slopes through gravel extraction and road building, and uncontrolled cottage development along the lakeshores, the scenic and environmental quality of the valley remains high in many places. Some locations support plant communities which have not been greatly modified by man's influence and wildlife abounds in the undisturbed marshes and woodlands. We hope that wildlife lands, representative biological communities, and areas supporting unique or endangered species will be set aside for the future.

The long term planning objectives of the Qu'Appelle Framework Plan generated a feeling of cautious optimism among many of those people concerned with preserving the natural environment of the valley. Some of the goals of this plan were to preserve, manage, and develop natural areas and fish and wildlife lands; to protect the aesthetic qualities of the valley; and to restore and avoid further disruption to indigenous ecosystems.

Unfortunately, little has been done to achieve these aims and, in fact, recent road construction within the Qu'Appelle simply ignores these objectives. To my knowledge, at least three recent projects of the provincial Department of Highways have considerably damaged the environment of the valley. A fourth project also poses a serious threat. The failure to consider potential environmental impact in the construction of valley roads has caused the scarring of hillsides and a reduction in the scenic qualities of the valley, the erosion of bare slopes and ditches, and subsequent water pollution by sediments carried from these areas by runoff, the creation of habitat for noxious weeds which invade agricultural, residential, and natural areas, and the destruction of natural ecosystems and important fish and wildlife habitats. Furthermore, some of the roads have questionable social or economic value. A brief description of the projects is given below.

\section{Highways 10 and 35 near Fort Qu'Appelle}

To improve travel along Highways 10 and 35, these roads have been rerouted out of the valley near Fort Qu'Appelle. The hillsides cut during construction have eroded badly and much sediment has been deposited in the Qu'Appelle River and Mission Lake. In one place, a stretch of railroad ditch about 200 feet long and 4 feet wide has been filled with 2 to 3 feet of hillside clay. An additional 1 to 2 feet of sediment has been deposited over an approximately 200 square foot area where this ditch empties into the lake. An untold amount of sediment was carried further into the lake. The \#35 highway bridge is another site where considerable sediment pollution is taking place.

Excess sediment damages aquatic ecosystems by reducing light penetration to green plants, using up oxygen in decomposition, reducing survival of fish eggs, decreasing the overall water quality, and doing physiological harm to the aquatic organisms. ${ }^{2} 37$ Sediments also contain nutrients which can stimulate excessive growth of algae and aquatic weeds. ${ }^{9}$ It is likely that the present disturbance is detrimental to the already strained 


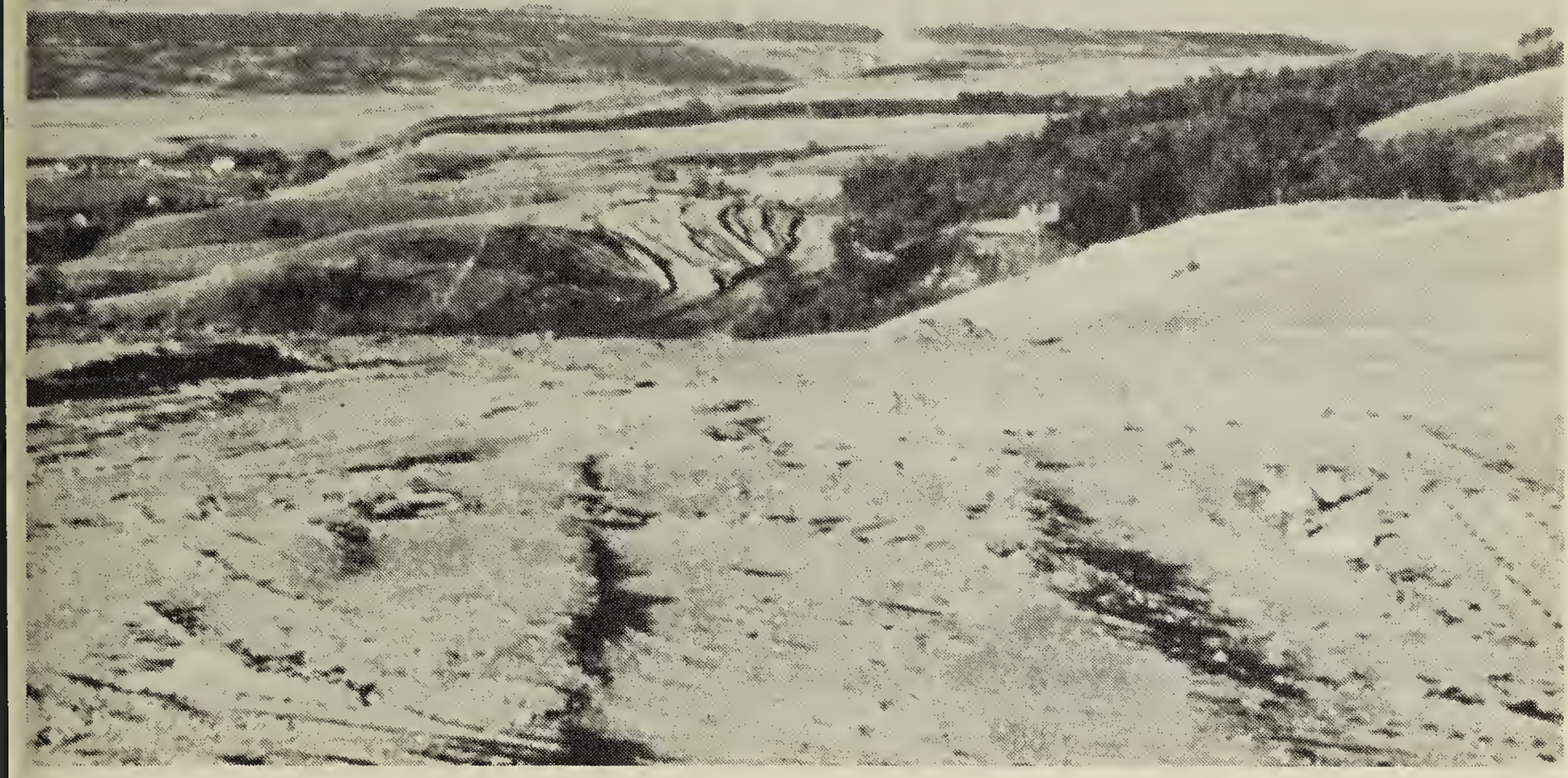

Construction of \#6 Highway across the Qu'Appelle Valley

Gary W. Seib

aquatic ecosystems of the Qu'Appelle for these reasons.

Until recently, no effort had been made to revegetate the barren hillsides and only stands of weeds such as Lamb's-quarters (Chenopodium album), Russianthistle (Salsola pestifer), Kochia (Kochia scoparia) and Sow-thistle (Sonchus arvensis) grow on the exposed slopes. A nearby cut from road construction during 1963-64 shows a slight improvement but the prevalent flora includes exotic species such as Yellow Sweet-Clover (Melilotus officianalis), Canada Thistle (Cirsium arvense) and Perennial Sow-thistle. Gullies up to four feet deep are still eroding there.

Before the slopes were destroyed, a dry grassland dominated by Spear Grass (Stipa commata), Blue Grama Grass (Bouteloua gracilis), Wheat Grasses (Agropyon spp.), and Pricklypear Cactus (Opuntia polyacantha) prevailed. A diversity of other prairie plants flourished. The hillsides, which had a history of little grazing pressure and occasional fires, were essentially a natural landscape, the type of ecosystem that the Qu'Appelle Basin Report emphasizes should not be disrupted. Now the slopes support nox- ious weeds and the beauty of the area has been marred by a maze of roads, the overpass, and the scarred hillsides. By locating the junction of these roads outside the valley, the whole problem could have been averted.

\section{Highway 6 North of Regina}

The relocation of \#6 Highway north of Regina has had similar, but less extreme, kinds of detrimental effects. Erosion also occurs at this site and the sparse vegetation consists of weeds. There has been no attempt to revegetate the abandoned part of the old highway.

\section{Highway 56 East of Katepwa Lake}

The rerouting of Highway 56 east of Katepwa Lake during 1975-76 constitutes a classical example of environmental ignorance or neglect on the part of a government agency. The new road passes directly through a marsh identified as a major fishspawning area during the $\mathrm{Qu}^{\prime}$ Appelle Basin Study. This wetland was of added significance to waterfowl and other wildlife. During highway construction, the river was channelized and the water level in the marsh declined, greatly diminishing its value as fish and wildlife habitat. Apparent- 


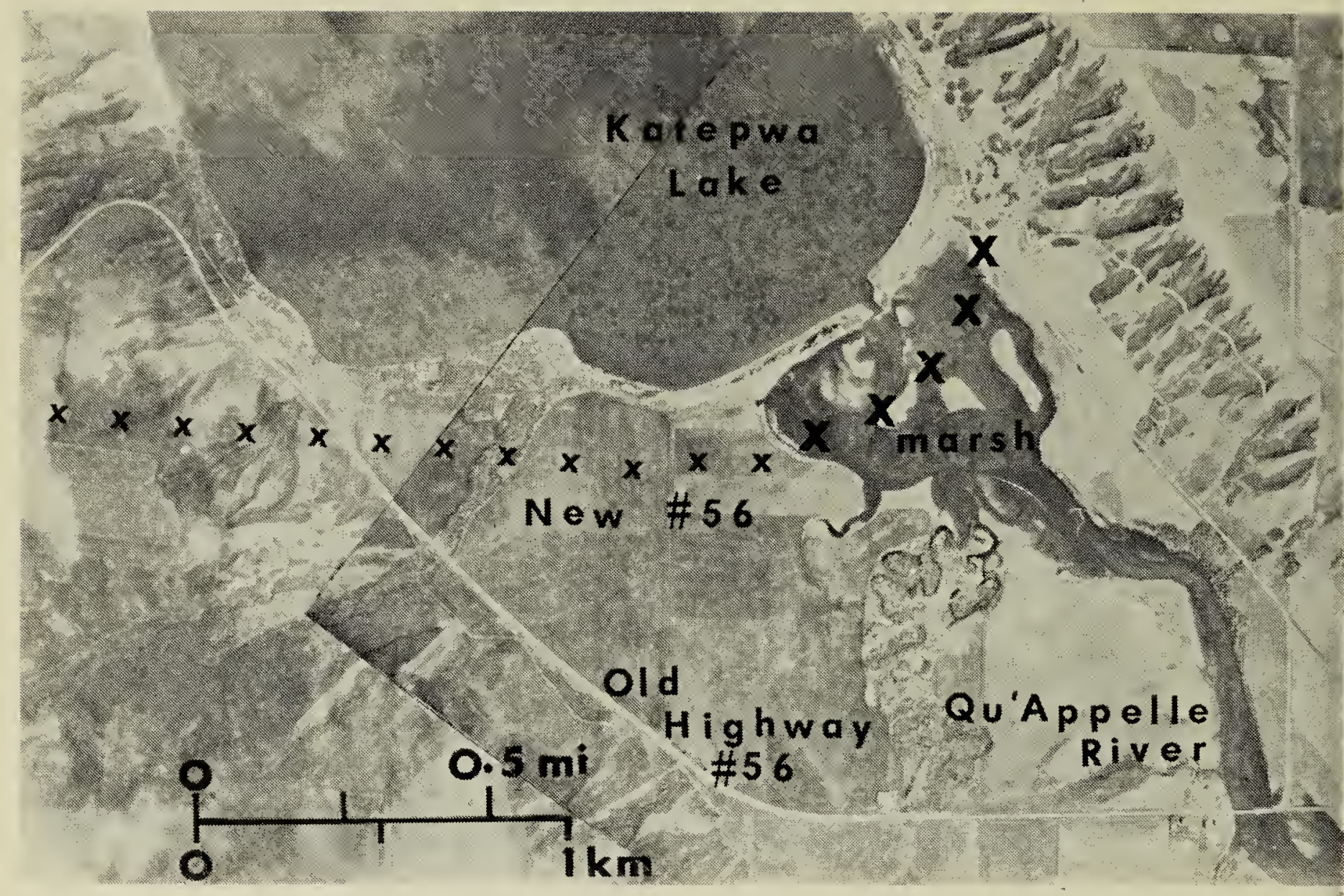

Route of \#56 Highway round Katepwa Lake

Jim Hines

ly, other government agencies were not consulted before the road was built and contruction was underway before its need could be questioned or its potential impact considered. The rerouting of Highway 56 was unnecessary as it shortens the distance travelled to the northwest side of the valley by only two miles. At that point it rejoins the old roadway. Based on average speeds of 60 miles per hour on the 2.2 miles of new highway and 40 m.p.h. on the old stretch, a motorist would save only 4.1 minutes by travelling on the new route. Should the natural quality of the valley be sacrificed (at considerable expense to the taxpayer) for dubious "improvements" such as this?

\section{Grid Road between Craven and Highway 6}

The road along the northside of the valley between Craven and Highway 6 is being modified to improve local farm access and to provide an alternate route to Regina during springs when Highway 20 is inundated by flood waters. Because the road is being "upgraded" to a 28 foot width, 60 mile per hour standard, fill will be "borrowed" from some hills, some curves will be straightened, and the steep hillsides will be contoured. This could cause even greater damage than that witnessed at the previously mentioned locations. Much of the problem would be avoided if a narrower, lower speed road was constructed along the original route.

\section{A Change in Attitude?}

The Department of Highways is either not aware of the recommendations of the Qu'Appelle Basin Study Board (which clearly opposes developments which are so damaging to the environment of the valley), or is ignoring these guidelines. Certainly, the attitude of some members of the department seems to be that "the hillsides look better when we are through with them" (a quotation from a Department of Highways official), but surely this indifference is not too widespread or impossible to change. Also at fault must be the Qu'Appelle Implementation Branch of the Department of the Environment (set up to carry out the 


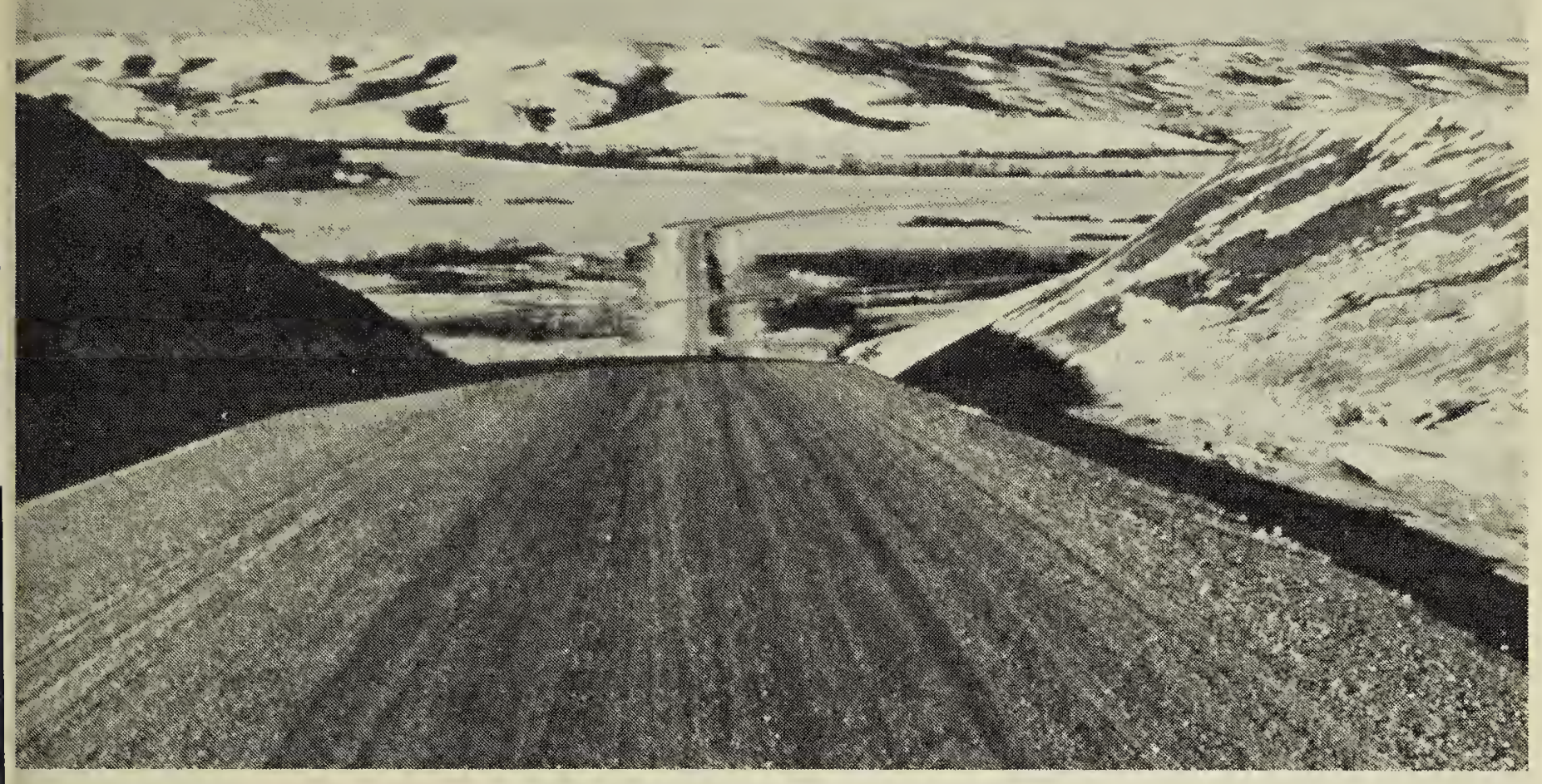

recommendations of the 1972 report) which has been neglectful in dealing with potential environmental damage.

Policies recently formulated by the provincial Department of the Environment and the Department of Municipal Affairs should help protect the valley from destructive projects in the future. The Department of the Environment will require that the potential impact is assessed for all major development projects, projects which might limit a resource, or are otherwise of major public concern. Recent amendments to the Planning and Development Act, administered by Municipal Affairs, will help guarantee that environmental damage and local socio-economic concerns are evaluated before new road construction is undertaken in the Qu'Appelle. These are both commendable steps which should do away with the current double standard that exists concerning impact statements - some agencies (such as the Saskatchewan Power Corpora(tion) must comply with a strict set of rules which are seemingly ignored by (or not applied to) other agencies uch as Highways. We hope that all agencies will have to adhere to a tricter set of standards in the future.

It is also hoped that at a time when the nebulous philosophy of "growth for the sake of growth" is being questioned, the Department of Highways will reconsider its "building roads for the sake of building roads" ideology and make enviromental protection a major priority. Assessment of potential impact and the development of procedures for landscaping and reclamation must become priorities in the planning stages if new roadways are to be compatible with the environment. To accomplish this, the department will need to consult specialists trained in disciplines such as ecology, hydrology, pollution control and landscape architecture.

Saskatchewan could learn a valuable lesson from the "Community and Environmental Factors Unit" of the California Division of Highways, which uses a multi-disciplinary approach to ensure that environmental factors are prominent in highway decision-making. ${ }^{8}$ Other states have also taken a positive approach in reclaiming roadside right-of-ways with native prairie plants. ${ }^{4}{ }^{5}$ Such restored prairies represent one of the last sanctuaries for the native grassland flora in many states and are also excellent for the prevention of soil erosion. Properly managed rightsof-way are productive wildlife habitat 
and frequently support the highest nesting densities of upland gamebirds and ducks. ${ }^{6}$ This type of habitat is especially important in intensively farmed lands where there is little other cover left for wildlife. With the introduction of a diversity of native plants, the roadside margins will support many kinds of animals.

Oetting 6 earlier suggested that the right-of-way resource could best be used for the conservation of native fauna and flora. In so doing, this vast acreage would be transformed from a liability (the maintenance cost for Saskatchewan highways and provincial roads was more than one million dollars in 1970) into a public asset. More importantly, the largely sterile, easily eroded, and unappealing roadsides would be converted into a healthy and scenic natural environment.

'Anonymous. 1972. Report of the $\mathrm{Qu}^{\prime}$ Appelle Basin Study Board. Queen's Printer, Regina. $x x x+65 p p$.

${ }^{2}$ GUY, H. P. and FERGUSON, G. E. 1970.
Stream sediment: an environmenta problem. Jour. of Soil and Water Conservation 25:217-221.

${ }^{3}$ HYNES, H. B. N. 1960 . The biology of polluted waters. Univ. of Torontr Press, Toronto. xiv +202pp.

${ }^{4}$ LANDERS, R. Q. 1972. The use of prairie grasses and forbs in lowa roadside and park landscapes. pp.180183. Second Midwest Prairie Conference, Madison. 242pp.

${ }^{5} \mathrm{ODE}, \quad$ A. H. 1972. A rationale for the use of prairie species in roadside-vegetation management. pp.174179. Second Midwest Prairie Conference, Madison, 242pp.

${ }^{6}$ OETTING, R. B. 1971. Right - of - way resources of the prairie provinces. Blue Jay 29:179-183.

'RITCHIE, J. C. 1972. Sediment, fish, and fish habitat. Jour. of Soil and Water Conservation 27:124-125

${ }^{8}$ ROSANDER, G. E. 1972. Environment: a new prominence in highway decision -making. Jour. of Soil and Water Conservation 27:121-122

${ }^{9}$ TAYLOR, A. W. 1967. Phosphorus and water pollution. Jour. of Soil and Water Conservation 22:228-231.

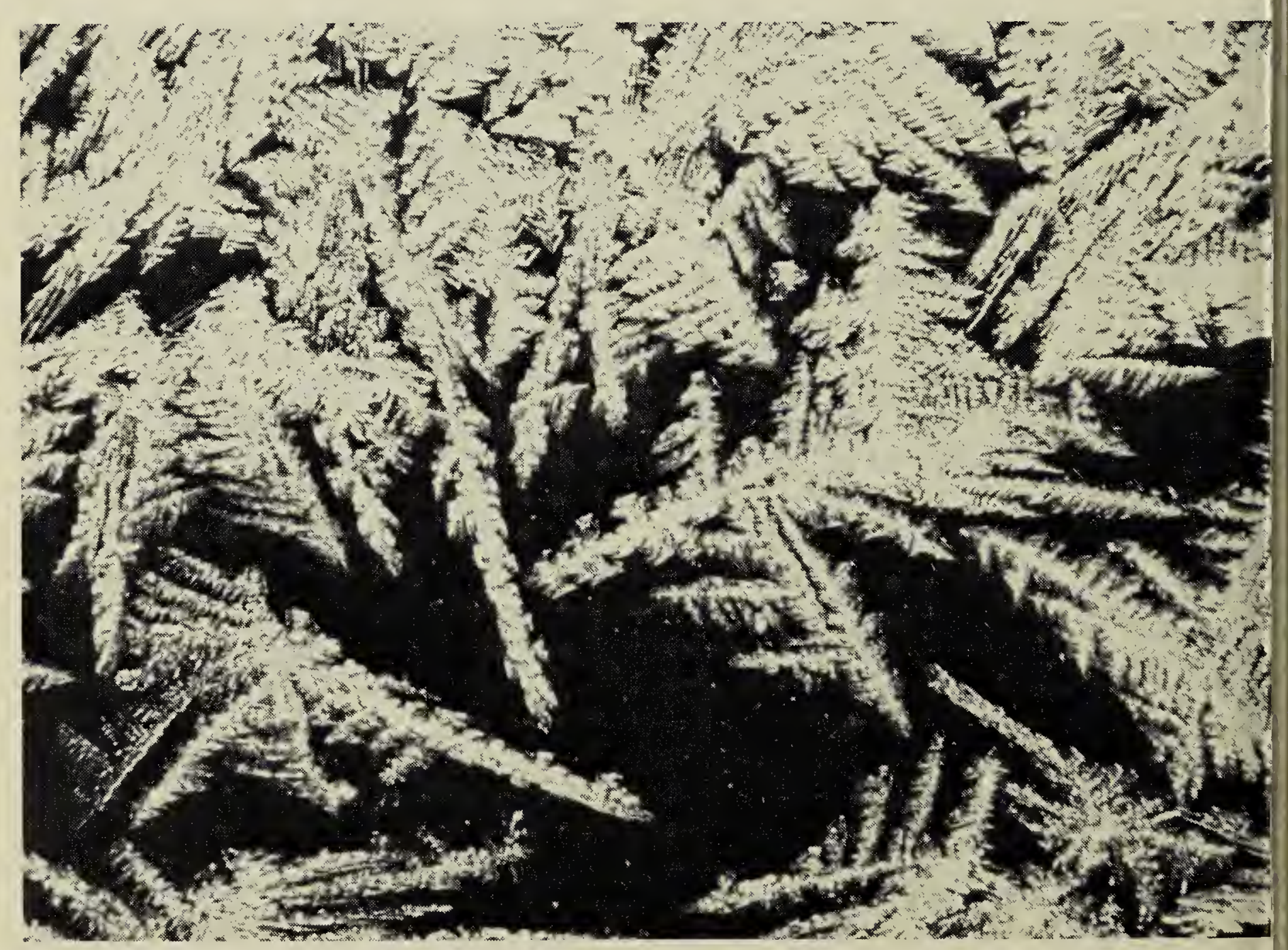

Frost crystals

R. E. Gehlert 